\title{
Regional-Local Executive Branch Conflict in El'tsin's Russia: the role of boundary control in Sverdlovsk Oblast
}

\author{
TOM CARTER \\ School of Slavonic and East European Studies, University College London
}

Conflicts between regional executive leaders and the executive heads of regional capital cities were a frequent occurrence in El'tsin's Russia, and were consequences of the rapid decentralization of power that occurred in the first half of the 1990s. This article focuses on the political competition that emerged in Sverdlovsk Oblast between the regional governor Eduard Rossel' and his counterpart at the local level, Ekaterinburg Mayor Arkadii Chernetskii. It evaluates the key network relationships held by these two actors during the 1990s, and asks how these networks influenced the balance of regional power prior to the federal recentralisation processes of the 2000s. The article applies the strategy of boundary control, as previously applied by Edward Gibson to the study of subnational regional regimes in Latin America under conditions of national democratization; ${ }^{1}$ in so doing, it considers Rossel"s hold over regional power as being determined by his approach to representing regional elite interests, both political and economic, which thereby insulated his power from challengers.

Disagreement and conflict between regional leaders and city mayors was commonplace in the El'tsin period for a number of reasons; they included the thirst for power among leading individuals, competing ideological forces, differences in available resources to coerce actors and elites, and a lack of legal clarity over local self-government in the new state. ${ }^{2}$ Within the intra-territorial conflicts at this time, the political competition between Rossel' and Chernetskii stands out for being largely conducted within the sphere of elections, combining informal and institutional competition based on respective personal appeal. ${ }^{3}$ While this conflict was publicly exercised through the city's electorate, who came to distinguish between oblast and city interests, it was privately focused around the ability

\footnotetext{
${ }^{1}$ Edward Gibson, Boundary Control: Subnational Authoritarianism in Federal Democracies, (Cambridge: Cambridge University Press, 2012).

${ }^{2}$ See, for example, Troyakova, T., 'A Primorsky Republic: myth or reality', Communist Economies and Economic Transformation, Vol. 10, No. 3, (1998), pp.391-404; Romanov, P., and Tartakovskaya, I., 'Samara Oblast': A Governor and his Guberniya', Communist Economies and Economic Transformation, Vol. 10, No. 3, (1998), pp.341-361.

3 Gel'man, V. and Golosov, G., 'Regional party formation in Russia: the deviant case of Sverdlovsk Oblast', Post-Soviet Affairs, Vol. 14, No. 1-2, (1998), pp.31-53.
} 
to acquire and distribute the resource requirements of the political and economic elite of the region.

\section{Foundations OF THE GovernOR-MAYOR CONFLiCT IN SVERDLOVSK ObLAST}

The difficult relationship between Eduard Rossel' and Arkadii Chernetskii lasted almost a decade and a half, from the mid-1990s to 2009. It can be viewed in terms of initially being a struggle for political control between the regional capital city, Ekaterinburg, and the rest of the Oblast, which then continued during the recentralisation process of the 2000 s, becoming a personal conflict between the two as the possibilities for regional political competition decreased.

The origins of the conflict between the leaders of the region and the regional capital in Sverdlovsk Oblast was initiated by the breakdown of prior patron-client relations between Rossel' and Chernetskii, prompted inadvertently by central intervention in Sverdlovsk regional politics. For regional regimes, the system of central appointment of regional leaders and loose oversight of regional regimes resulted in the development of personalised power, which prioritised its own preservation. This led to the emergence of neopatrimonial regional power, in which informal group ties, loyalty to the patron and formal positions appeared as core factors used to privatise gains. ${ }^{4}$ Heads of local government in Russian cities and towns under El'tsin were also initially conducted via central appointment, although based upon the recommendation of the previously appointed heads of regional administration (governors). ${ }^{5}$ Different pressures according to the location and composition of the city affected these recommendations, and attention had to be paid to the competing interests of different sections of the elites therein. ${ }^{6}$ Within existing patron-client structures, entrenched clients were potentially able to influence leader's choices by lobbying for or against the entry of new clients. ${ }^{7}$ Much like its citizens'

\footnotetext{
${ }^{4}$ Gero Erdmann and Ulf Engel, Neopatrimonialism Revisited - Beyond a Catch-All Concept, GIGA Research Program: Legitimacy and Efficiency of Political Systems, No.16, (February 2006).

${ }^{5}$ Gel'man, V., Ryzhenkov, S., Belokurova, E., Borisova, N., Reforma mestnoi vlasti v gorodakh Rossii, 1991-2006, (Saint Petersburg: Norma, 2008), pp.58-9.

${ }^{6}$ See the example of the ethnic republics of Sakha and Tatarstan in Mary McAuley, (1997), Russia's Politics of Uncertainty, (Cambridge: Cambridge University Press, 1997), and six Oblasts (Saratov, Nizhnii Novgorod, Volgograd, Ryazan', Ul'ianovsk and Tver') in Vladimir Gel'man., Sergei Ryzhenkov and Michael Brie, Making and Breaking Democratic Transitions: The Comparative Politics of Russia's Regions, (Lanham, MD: Rowman \& Littlefield, 2003).

${ }^{7}$ Archie Brown makes this underlying point in his discussion of the changes in personnel in the higher echelons of the Soviet Communist Party conducted by Gorbachev at the beginning of his leadership - that members of the elite could have blocked Gorbachev from making many of the appointments that he did,
} 
socioeconomic security, in the immediate aftermath of the collapse of Soviet rule regional political power incurred its own struggle for day-to-day survival, rooted in matters of loyalty and various capacities to obtain and distribute resources.

Following his appointment in October 1991 as Head of Regional Administration in Sverdlovsk Oblast, Rossel' quickly demonstrated that he understood the nuances of his position. To balance the uncertainty from above (where the victory of 'pro-reform' forces was not yet assured) he realised the value of support from the most influential sections of the regional economic elite. The appointment of his own proposed candidate as mayor of the region's capital city was an early test of his local authority. It was therefore critical that he not be challenged over this choice, particularly by the very elites that he supposedly represented. In one of Russia's most industrialised regions, support for Rossel”s proposed candidate was balanced within the framework of what the industrial elite of Ekaterinburg saw themselves potentially gaining from the new political order. In the few months that had passed since the final collapse of the Soviet system, the prominent position that industrial directors had previously held in the region had hardly changed despite economic collapse in the heavy industry and military-industrial sectors. Thus, the choice of Arkadii Chernetskii, the General Director of the Uralkhimmash factory in the city, one of the largest industrial plants which dominated the southern part of the city, proved uncontentious and carried the support of other members of the city's director-elite. ${ }^{8}$ While never personally close to him, the convenience of this candidate served to lend Rossel' legitimacy with the industrial elite and signal his willingness to maintain the structural status quo ante of the recent past, under which the interests of the military-industrial complex, heavy industry and construction figured high on the agenda. With a highly politicised public in one of the most pro-reform regions of the state, the directors of a number of other large enterprises from the city, including the influential Uralmash (Uralskii Mashinostroitel'nyi Zavod) plant, firmly supported Chernetskii's nomination and praised the new Mayor's 'managerial qualities' and 'suitability' for the post. ${ }^{9}$ In selecting a candidate from within the existing 'director corps', Rossel' had

\footnotetext{
but that they themselves saw the potential benefits of a certain amount of reform. Archie Brown, The Gorbachev Factor, (Oxford: Oxford University Press, 1996), pp.53-129

${ }^{8}$ Interview with Anatolii Kirillov (Urals El'tsin Centre, Ekaterinburg, March 2011).

9 'Dolzhen byt' podderzhan', Ural'skii rabocbii, 14 January 1992, p.2. Chernetskii had initially presented a list of material demands should he be chosen for the Mayoralty, which the regional press seized on as being unreasonable and somewhat greedy. The directors of a number of industrial enterprises quickly countered this with an open letter to the Ural'skii rabocbii paper stating that 'the Mayor of such a city should be supported both morally and materially more than others'. The significance of the industrial structure of the region and the city should not be lost here, as the onus of the Soviet social contract shifted to make citizens ever more reliant on their employers.
} 
taken care to acknowledge the primacy of the industrial elite in the region, and acquired their support to begin the legitimisation of his leadership.

With the governor appointed by the centre, and with the position of Mayor not legitimated by popular elections, Chernetskii found himself tied to Rossel"s patronage. The new Mayor's managerial knowledge of industry in the region complemented Rossel"s own enterprise management experience, and was promoted as being of vital importance in preventing socioeconomic conditions from spiralling further downwards in the regional capital. Chernetskii's managerialist approach to running city affairs chimed with Rossel"s at the regional level, and both figures constructed teams according to their ability to meet the needs of the position rather than to ideological leanings. Choosing experience and knowledge over political ideology, or stability and pragmatism over uncertainty (the very characteristics that Rossel' pronounced himself to espouse), there are echoes of the choice that El'tsin made in appointing Rossel' as regional leader. ${ }^{10}$ As expected under the terms of patronage, Chernetskii supported the governor politically in return for assistance from the regional administration in financing and running the city. For example, he offered cautious support to Rossel"s unilateral attempt, in 1993, to increase the federal status of the region by declaring a Urals Republic to replace Sverdlovsk Oblast. ${ }^{11}$

The breakdown of the patron-client relationship occurred towards the end of 1993, when Rossel' was dismissed by El'tsin for overstepping his authority with this declaration. With Rossel"s dismissal, the patron-client relationship that Chernetskii had been incorporated into ceased to exist, with the Ekaterinburg Mayor remaining in his position and Rossel' no longer holding any political leverage over him. Patron-client network theory suggests that it is possible for informal relations to continue after roles have been institutionalised, undermining these institutions and hindering their development. It further notes that a mutual dependency emerges between patron and client over the exchange of resources, stunting the will of actors to eventually break free from such ties. ${ }^{12}$ While it is

\footnotetext{
${ }^{10}$ See the interviews with Arkadii Chernetskii in Ural'skii rabochii immediately prior to and after his appointment as Ekaterinburg Mayor by El'tsin. 'V mery ne naprashivalsia', Ural'skii rabocbii, 18 January 1992, p.1 and 'Zhit' stanet luchshe?', Ural'skii rabochii, 13 February 1992, p.1.

11 As the regional branches of power were located in Ekaterinburg, there was much opportunity for city and regional branches of power to exchange views. This did not, however, extend to other cities. Nikolai Didenko, the mayor of Sverdlovsk Oblast's second city, Nizhnii Tagil, complained about the lack of attention paid to local self-government by Rossel' and his government and spoke of poor region-city ties outside of the capital. 'Nam ne khvataet optimizma', Ural'skii rabochii, 12 March 1992, p.1.

12 Shmuel Eisenstadt and Luis Roniger, Patron, Clients and Friends, (Cambridge: Cambridge University Press, 1984), p.234 cited in Katharina Hoffman, 'Informal politics and multilateralism in the post-Soviet space. Ukrainian foreign policy towards the CIS and GUAM', research paper, Research Centre for East European Studies at the University of Bremen, Changing Europe Summer School V, Prague < www.changing-
} 
logical to suggest that patron-client ties become deeper and more mutually infused with time, in this case there was insufficient consolidation of patronage relations and considerable uncertainty over the future exchange of resources, which resulted in Chernetskii's exit from the network. ${ }^{13}$ Once 'reciprocal dependency' ${ }^{14}$ lost its relevance, Rossel' found that he was no longer in a position of control over Chernetskii.

Following Rossel"s dismissal, the Ekaterinburg mayor may well have expected himself to become the next governor of the region, but it was one of his own deputies, Aleksei Strakhov, who was subsequently appointed by El'tsin. While this could have led to antagonism between the mayor and the newly appointed governor, close and cooperative ties developed between the two particularly as Strakhov did not attempt to become patron to Chernetskii. ${ }^{15}$ Rossel' quickly returned to regional political life as one of the region's representatives in the Federation Council, and soon afterwards was elected to the new Sverdlovsk regional Duma. However, there was no revival of his influence over the city mayor, who, growing in political confidence, belatedly began to speak out against the Urals Republic and advocated an allocation of powers between federal and regional, and regional and city, conflicting with that of his former patron. The stance that Chernetskii took up with regards to the centre and on the allocation of regional-local government powers established his political identity, and following Rossel"s defeat of Aleksei Strakhov in the 1995 Sverdlovsk governor elections, the Ekaterinburg Mayor became Rossel"s main political opponent.

\section{II. 'Boundary Control' as A STRATEgY For CoNTRolling THE REgionaL POLITICAL SPHERE}

Having outlined the positions leading up to the governor-mayor conflict in Sverdlovsk Oblast, we can now look to the measures taken by Rossel' to limit the effects of this

europe.de/index.php> [accessed 10 April 2012]. Howard F. Stein, 'A note on patron-client theory', Ethos, Vol. 12, Issue 1, (1984), pp.30-36.

13 On the consequences of shifting expectations of clients over the ability of their patrons to deliver resources, see Henry Hale, Patronal Politics: Eurasian Regime Dynamics in Comparative Perspective, (Cambridge: Cambridge University Press, 2015).

${ }^{14}$ Stein (1984), p.34.

15 Interview with Gennadi Korobkov (Ekaterinburg, December 2011). Korobkov was Strakhov's deputy governor from August 1994 to August 1995 in charge of relations with society. Korobkov noted the closeness of political ties between Strakhov and Chernetskii while the former was regional leader, thus allowing for a strong degree of close coordination between the city and the regional administrations in this period. 
competition to his leadership, using the boundary control theory to outline how he sought to preserve his power.

Extending the power reproduction theory, where elites seek to safeguard their political direction by permitting only those with comparable beliefs into their political spheres, the idea of 'boundary control' was examined in Edward Gibson's research on subnational authoritarian regimes in Latin America as a form of power preservation for leaders to protect their own position within regimes. ${ }^{16}$ Boundary control is defined as a strategy that protects outsider action or actors from entering occupied political territory before the point of the reproduction of power arises. Gibson explored the use of this strategy by regional leaders in Mexico and Argentina, looking to maintain their power under conditions of national democratization by acting to prevent political opponents' access to resources and allies. Exploiting those resources available to the incumbent leader, in particular through the unequal balance of forces that these leaders enjoyed, the sub-national regimes, which were already in place and long-standing when the national political arena began its democratization process, continued to pursue authoritarian practices.

While the political regime under Rossel' was not authoritarian, the boundary control approach can be transposed onto the case of sub-national power in Russia, due to the simultaneous process of national and sub-national transition that was occurring as well as the lack of central ability to influence the development of subnational regimes. In the absence of institutionalised and enforced rules applied by the national government upon subnational government, boundary control offers a strategic method of operation whereby a 'controlling area' is established that allows regional leaders to "[monopolise] power in the local political arena, but also [manipulate] levers of power in other arenas as well. It requires controlling linkages between levels of territorial organization as well as exercising influence in national political arenas." 17 The uncertain nature of Russian subnational leadership throughout the 1990s created conditions in which, under the system of presidential appointment of regional leaders and even following subsequent popular election, leaders were forced to protect personalised power rather than construct institutions that would secure the successful transferring of power. Regional leaders' positions combined formal and informal methods to limit competition and ensure the monopoly over administrative resources that might otherwise be used against them. Boundary control is, therefore,

${ }^{16}$ Falleti and Lynch, 'Context and Causal Mechanisms in Political Analysis', Comparative Political Studies, Vol. 42, No. 9, (2009), pp.1143-1166; Gibson (2012).

${ }^{17}$ Edward L. Gibson, 'Boundary control: subnational authoritarianism in democratic countries', World

Politics, Vol. 58, No. 1, (2005), p106. 
considered here as the mechanism applied by Rossel' to convert the inputs (elites, resources and networks) to an outcome of continued regional political power. The arguments put forward in the analysis of Rossel"s actions are intended to show that this behaviour was intentional and, importantly, fulfilled the aims that it set out to achieve. This helps us to understand Rossel' as both an individual and as an institutional actor (at the heart of a collective political system), insulating himself from rivals. Examining the development of and participation in numerous, distinct and overlapping networks made up of the federal and regional elite (political and economic) and as influenced by Rossel"s character provides the inputs which resulted in consolidation and preservation of his regional power.

Three essential factors are required of the regional leader in the boundary control strategy, and these are proposed as being effective against the challenge that Chernetskii posed to Rossel"s leadership:

- the monopolisation of national-sub-national linkages (ensuring that only Rossel' had control over decision-making networks and contacts with the centre, so as to force elites to go through him to advance their causes nationally);

- the nationalisation of influence (Rossel"s ability to be the only actor from Sverdlovsk Oblast capable of pursuing strategies at the national level that would influence regional interests);

- the parochialisation of power (the ability to ensure hegemony over the subnational territorial system, making the elite and the wider general public in the region absolutely reliant on his goodwill). ${ }^{18}$

Several themes are highlighted below in governor-mayor relations in Sverdlovsk Oblast that demonstrate Rossel"s use of boundary control. Firstly, we look at Rossel"s ties with El'tsin and how this was portrayed in order to monopolise national-regional linkages. Secondly, we look to Rossel"s control over local self-government within the region. The clear contradictions between Rossel"s previously advocated positions on centre-regional relations and his behaviour towards local self-government in general (not only with regards to Ekaterinburg), with 62 towns and cities and 73 municipal (and district) entities in the region by 1998 , demonstrate his ability to bring the local elites under his influence. ${ }^{19}$ The discussion next looks at Rossel"s and Chernetskii's competing regional political movements as the conflict was brought into the open and as both sides sought to popularise their

18 Gibson (2012), pp.26-29.

19 'Kak podelish', tak i poznesh', Ural'skii rabochii, 4 February 1998, p.2. 


\section{CARTER - REgIONAL-LOCAL EXECUTIVE BRANCH CONFLICT IN EL'TSIN’s RusSiA}

legitimacy. While these political movements did indeed lend an air of pluralism to the political space, they competing at fundamentally different levels, with Chernetskii's own political party 'Our Home, Our City' (Nash Dom Nash Gorod) largely restricted to support within Ekaterinburg, affirming Rossel"s hegemony in national politics. Finally, the importance of the industrial elite to both actors is considered, noting how the importance of meeting this sector's demands influenced the outcome of regional-local competition in the region.

\section{THE IMPORTANCE OF EL'TSIN IN SVERDLOVSK OBLAST}

The degree of knowledge that El'tsin had of his regional leaders varied heavily from region to region, and in many cases, appointments were made upon the recommendation of those close to the president or by prominent pro-reform actors within the regions. ${ }^{20}$ As a result, the head of state often had little prior knowledge of, and certainly no personal relationship with, a number of his appointees. With the development of Russia's regions far down the list of the centre's priorities, regional leaders were presented with little in the way of regular formal contact with El'tsin, who passed the responsibility for everyday contact with the provinces to his government and newly created Presidential representatives (his supposed eyes and ears in the regions). ${ }^{21}$

The case of Rossel' is one where a prior history between both already existed, going back to El'tsin's days as Regional First Party Secretary of Sverdlovsk Oblast. The existence of such ties contributed much to relations between the region and the federal centre, largely centring upon patronage ties between El'tsin and Rossel'. As the case of the Urals Republic underlined, policy initiatives from below threatened the state's perception of emerging federal relations; without the centre's agreement, unilateral actions from the regions carried a large degree of risk. In matters concerning centre-regional relations, Rossel' pursued policies without the centre's approval prior to his dismissal, while following his election to the regional Duma in 1994 he clearly sought presidential permission for policies that affected relations with the federal authorities. Under the new approach, a perception was

\footnotetext{
${ }^{20}$ Interview with Gennadii Burbulis (Moscow, September 2011).

21 The willingness of regions to take the initiative in relations with the centre also varied greatly. Examples of regions that were more passive are Perm Oblast and Tver Oblast (see Gel'man, Ryzhenkov and Brie (2003), pp.215-242, and McAuley (1997), pp.156-173). Other regions, such as those involved in the Siberian Agreement attempted to dictate a relationship with the centre on their own terms (see James Hughes, 'Regionalism in Russia: the rise and fall of the Siberian Agreement', Europe-Asia Studies, Vol. 46, No. 7, (1994), pp.1133-1161).
} 
cultivated that a 'special relationship' existed between the President and regional leader; this became central to Rossel"s idea, which he and his supporters promoted to the elites and the region's general population, that only he was capable of negotiating with the President in a way would benefit the region. The view was constructed that El'tsin and Rossel' could personally agree on terms, whereas other actors (most clearly contrasting Rossel"s successor as governor, Aleksei Strakhov, and later Chernetskii) were unable to build strong connections with the president and as a result lacked a route to the top to negotiate on behalf of the region. The achievement of a regional charter, gubernatorial elections, and a bilateral treaty, which were all instigated by Rossel', furthered this notion and portrayed the impression that El'tsin trusted him to experiment with regional structures (ignoring the very real interest he had in preserving his own position through granting concessions to regions in exchange for support). This special relationship with El'tsin became a key part of the boundary control strategy employed by Rossel' to prevent competitor encroachment into his own political territory and prevent the outflow of support from the critical elites that would provide dependable electoral and regime support in subsequent electoral competition with Chernetskii.

\section{LOCAL SELF-GOVERNMENT IN RUSSIA AND THE GROUNDS OF GOVERNOR- MAYORAL CONTEST}

Local self-government has historically played a mixed role in the development of Russian society. From the zemstvo reforms of the nineteenth century, with its low-level rights for local formations to manage a closely limited sphere of powers, to early Bolshevik demands for 'all power to the Soviets', with local councils being formed at all levels, a functioning system of local self-government that could resolve specific local problems at the level at which they arose (and independently of the bureaucracies underlying the tsarist guberniia and the communist system of subordination) remained elusive. ${ }^{22}$ Under the reforms of the early 1990s, local self-government became a contested area of political control between regional administrations and its units, focused around the allocation of (financial) resources, the division of property and the pace and results of privatization.

According to the 1993 constitution, local self-government was officially outside of state power. In practice, however, the interests of regional power could easily be projected

\footnotetext{
22 See Gel'man, Ryzhenkov, Belokurova and Borisova (2008), pp.38-98, for an account of the development of local self-government from the $19^{\text {th }}$ century to the modern day.
} 


\section{CARTER - REgIONAL-LOCAL EXECUTIVE BRANCH CONFLICT IN EL’TSIN'S RuSSIA}

onto the local level, using administrative resources to seek the elections of allies to local positions and to coerce opponents into obeying the de facto hierarchy of power. Regional capital cities and larger cities in the provinces were the strongest units of local selfgovernment and generally the most capable of contesting this, whereas small towns were unable to resist regional pressures. As the shift of responsibilities transferred from the state to the regions, which in turn passed the burden of maintaining the social contract onto local self-government, the latter faced the rising costs of providing public utilities, housing, education services and basic social welfare on budgets that were inadequate to deal with such socially vital responsibilities. For the larger cities and districts this affected, seeking additional rights of taxation, budget formation and control over the privatization of property in order to pay for the essential services required in their territory frequently brought them into conflict with regional administrations. ${ }^{23}$

Building a new and functional system of local self-government in the new Russian state was not something that held a great deal of interest to members of the federal or regional elite. Prior to a federal law outlining the principles of local self-government eventually being passed in 1995 (and only as pressure grew to have such a law in place before Russia joined the Council of Europe), regional leaders had been able to actively hinder the development of any formal delineation of the powers of local self-government at the level of the Federation Council. This had been done on the basis that it was against their interests to allow the development of local power outside of their influence or, worse, to permit elections to local and district executive bodies, removing their powers to appoint and dismiss city, town and district leaders. ${ }^{24}$

In Sverdlovsk Oblast and its capital, Ekaterinburg, these conditions contributed to the conflict between Rossel' and Chernetskii, and local government issues grew in intensity following the former's election as governor in August 1995. Many of the issues that provoked conflict between the two related to their own ideas surrounding the nature of regional power, particularly the division of powers and allocation of authority, resulting in a struggle for control over resources (political, economic and physical) at their respective levels. In early 1995, with the cascading system of legal hierarchy still to be put into effect,

\footnotetext{
${ }^{23}$ Gel'man, Ryzhenkov, Belokurova and Borisova (2008) estimate that $75 \%$ of local self-government budget was spent just on housing, education, health care and welfare payments (p.29). The upkeep and privatization of other vital infrastructure such as electricity, water, heating, roads and public transport were among areas requiring the attention of local self-government.

${ }^{24}$ Patrons need to be elected before the clients or else risk losing control and influence over them, in the same way that many in the centre wanted presidential elections to be held before gubernatorial elections. Gel'man, Ryzhenkov, Belokurova and Borisova (2008), pp.95-96
} 


\section{CARTER - REgIONAL-Local EXECUTIVE BRANCH CONFLICT IN EL’TSIN’s RusSia}

the Sverdlovsk Oblast Duma, chaired by Rossel', wrote and passed a regional law on local self-government before the federal law had been passed. This move that was viewed by Chernetskii as both hostile and premature, since it promoted adherence to regional law even before its obligations under federal law had been fully understood. Alongside Rossel"s pursuit of gubernatorial elections in summer 1995, he and his clients in the Oblast Duma began to press for an early mayoral election, as Chernetskii's mandate was set to expire in March 1996. Efforts to hurry elections in the hope that one side would be underprepared is normally used by the incumbent trying to limit the campaigning time of rivals; in this case, the pro-Rossel' camp in the regional Duma saw an opportunity to force the pace of mayoral elections, proposing holding them on the same day as gubernatorial elections in August, in the hope of linking their own candidate for mayor, Anton Bakov, to Rossel's gubernatorial candidacy, while connecting Chernetskii to Strakhov. ${ }^{25}$ This strategy did not succeed, and the pro-Rossel' regional Duma was unable to force early mayoral elections due to the lack of laws specifying the procedure for mayoral elections (popular election or election by the City Duma), and they were delayed until mid-December 1995, to be held on the same day as the RF Duma elections.

Further pressure on the Mayor of Ekaterinburg, and local self-government more widely, followed with the introduction of a system of prefectures. This came partly as a response to mayoral elections and underlined the contradiction in Rossel"s own views on centre-region relations with Moscow and his attitudes towards internal power in the region. The series of bilateral treaties agreed between Sverdlovsk Oblast and Moscow following Rossel"s return to regional executive power in the August 1995 gubernatorial elections delineated those powers that were to be of federal-only, regional-only and joint jurisdiction. Chernetskii argued that the next logical step was to complete a similar process between region and local self-government to provide the final link in the chain of state structure. ${ }^{26}$ Having achieved the desired transfer of powers from the centre, Rossel"s rhetoric on state structure toughened significantly; having previously only demanded greater rights to be transferred downwards, he now spoke openly about the need to strengthen state vertical power (notwithstanding agreements already reached between centre and region). With the executive and legislative branches working in tandem, Rossel' controlled the debate, arguing

${ }_{25}$ Grigorii Golosov, Political parties in the regions of Russia: democracy unclaimed, (Boulder, CO: Lynne Rienner Publishers, 2004) p.130. Bakov was at this time formally part of the Party of Russian Unity and Accord (PRES) but was closely linked to Rossel' and the Preobrazhenie Urala movement, although was not formally put up for election by Rossel"s movement (Aleksei Ivanov, Eburg, (Moscow: Izdatel'stvo AST, 2014), p.239).

26 'Poluchil vlast', peredai dal'she', Ural'skii rabochii, 28 February 1996, p.1. 


\section{CARTER - REgIONAL-LOCAL EXECUTIVE BRANCH CONFLICT IN EL’TSIN'S RuSSIA}

that increasing the rights of local self-government threatened to undermine the powers of the governor, who would no longer have any oversight over heads of local self-government now that they were elected. ${ }^{27}$ This proved a weak argument, not least because through control over both branches of regional power Rossel' had regained the monopoly over the allocation of administrative resources - such as control over (and delay of) fiscal transfers, and the transfer of regional property to municipal funds - that could be used to apply pressure on local actors not acting according to the regional executive's wishes, even after popular elections to local self-government formations. ${ }^{28}$ The introduction of prefectures applied increased pressure on local self-government formations in the region in return for obedience. That this was implemented in violation of federal and regional laws on the separation of powers did not slow down the process, as pro-Rossel' officials, already holding administrative positions in local self-government, were appointed prefects. ${ }^{29}$ In Rossel"s view, having local self-government outside the vertical power system, that is to say not directly subordinate to regional power, increased the reality of the erosion of central power and the disintegration of the state (a key theme in Moscow's rejection of the Urals Republic). ${ }^{30}$ Ironically, he attacked what he claimed to be his opponent's 'demagoguery' with regards to local self-government, claiming that Chernetskii was interpreting local selfgovernment as the concentration of total power in the hands of one person at the head of local administrations. ${ }^{31}$

\footnotetext{
27 'Skvoz' status zamertsali vybory', Ural'skii rabochii, 27 February 1997, p.1.

28 Anatolii Kirillov spoke about the lack of competition in the region and the various administrative resources available and used by Rossel' and his team over regional politicians. With control over the allocation of property to the municipal level and influence among the industrial elites, for example, pressure could easily be applied to the local level, not only by prefects but by the regional leadership also.

29 'Viktor Mikhel': Sovmeshchenie dolzhnostei - promezhutochnyi variant', Oblastnaia gazeta, 19 February 1997, p.1.

30 'Otvet krizisu - ideia gosudarstvennosti - doklad gubernatora Rosselia na XIV s"ezde obshchestvennogo nepartiinogo ob"edineniia "PU” 17 aprelia 1999, g. Nizhnii Tagil', Oblastnaia gazeta, 21 April 1999, p.3. At the $14^{\text {th }}$ Congress of Preobrazhenie Urala in April 1999 (while Rossel' was building his political movement to go federal to compete in the 1999 RF Duma elections), he said there were three options for strengthening the state; a return to the past in the unitary state, a confederacy (prompted by local self-government), which would lead to disintegration, or his way, the creation of prefectures to supervise local self-government. 31 'Vystuplenie gubernatora Sverdlovskoi oblasti E.E. Rosselia, lidera obshchestvennogo nepartiinogo ob"edineniia "Preobrazhenie Urala" na 12-m s"ezde ob"edineniia 7 fevralia 1998 goda", Oblastnaia gaz̧eta, 10 February 1998, p.1-2.
} 


\section{Ekaterinburg Versus Sverdlovsk: A Case of Asymmetric Party COMPETITION}

Previous studies of the application of boundary control in Latin American postauthoritarian states have noted that the parochialisation of power in Mexico and Argentina was facilitated by the presence of hegemonic (or near-hegemonic) regional branches of federal parties. The formal connection between subnational leader and federal party was based on the national ruling party's support for the subnational leader in return for the delivery of votes from the region. In the case of Russia, weak federal political parties dominated the El'tsin decade, with several attempts to create parties of power failing to gain traction in federal elections. In the case of Sverdlovsk Oblast, we can observe examples of regional parties, centred around individual figures, that aimed to control the formal political space of the region, while implementing a subnational system of the support for votes structure observed under the patronage conditions described above.

While the political space in Sverdlovsk Oblast has been noted as being conducted within agreed rules, and with all sides obeying the outcomes, ${ }^{32}$ the strength of Rossel"s individual influence throughout the entire region meant that competition was heavily weighted in his favour. The inaugural Ekaterinburg mayoral elections, finally held in December 1995, were fought around issues that had been played out during the recent gubernatorial campaign and were still fresh in citizens' memories. Campaigning focused on the future of regional and local integration into the state structure - Chernetskii advocating greater devolution of power to local self-government, against Rossel"s candidate, Anton Bakov, who was campaigning on a platform of greater integration of the city into the system of regional power and returning the mayor's post to the patronage of the governor. The incumbent mayor's victory was comprehensive, and should be viewed through the prism of the fallout from the gubernatorial battle between Rossel' and Strakhov; the results of the RF State Duma elections in the city that were held on the same day as mayoral elections showed a clear division along a region-city axis in voting behaviour. In Ekaterinburg, the Our Home is Russia party (Nash Dom Rossiia) for which Strakhov was the regional head of party, came out on top with approximately 12 percent of the city vote compared to Rossel"s Preobrazhenie Otechestva (Transformation of the Fatherland) movement (the federal branch of his Preobrazhenie Urala - Transformation of the Urals - movement that dominated the

\footnotetext{
32 Gel'man, Ryzhenkov and Brie (2003).
} 
regional Duma), which polled fifth in the city with eight percent of the vote. ${ }^{33}$ Conversely, the results for the entire oblast put Preobrazhenie Otechestva in first place, with 12.1 percent of the vote and Nash Dom Rossiia third, behind Zhirinovskii's LDPR, with 8.35 percent, underscoring the differences between the regional and capital city electorates. ${ }^{34}$ On the basis of the endorsement received from the city, Chernetskii became the figurehead of his own political movement Our Home, Our City (Nash Dom Nash Gorod - NDNG) in early 1996, following an agreement with Nash Dom Rossiia, in order to compete against Rossel' in the regional political space. NDNG closely followed the model chosen by Rossel"s rival Probrąhenie Urala, constructing its political identity almost entirely around Chernetskii as an individual. ${ }^{35}$ Its aims were noted as being primarily 'to protect the interests of the city' (against regional-level transgressions), and it focused its campaigns for regional Duma elections in 1996 and 1998 on having the regional law on local self-government rewritten, since by now it clashed with recent federal law. ${ }^{36}$

The long-reach of Rossel"s influence throughout the Oblast', particularly in relation to the industrial sector and its reliant population, left Chernetskii struggling to make himself relevant outside of Ekaterinburg. The pool from which he could draw support was diminished as elections to local self-government became the norm and a large number of heads of local administration joined Preobrą̧henie Urala in return for official appointment and the delaying of any competitive local elections, leaving those candidates who did attach themselves to the NDNG movement beyond the networks of the ruling elite. ${ }^{37}$ The result of this was that during the 1996 regional Duma election campaign, no matter how much Chernetskii and NDNG attempted to push into the provinces, it found itself drowned out by Rossel"s capacity to override local issues with those of the region. Success within the regional capital resulted in NDNG becoming an established political party in the regional Duma, and a counterweight to Preobrą̧henie Urala in the regional legislature; in the 1998 Oblast Duma elections NDNG obtained sufficient deputies to prevent Preobrazhenie Urala

\footnotetext{
33 'Gaidar vperedi ne shagaet', Oblastnaia gazeta, 22 December 1995, p.1. Rossel”s federal political movement polled behind Iabloko, Demokraticheskii Vybor Rossii and the distinguished eye surgeon Stanislav Fedorov's Partiia samoupravleniia trudiashchikbsia overall within the regional capital's electoral districts. ${ }^{34}$ Ibid.

35 'Arkadii Chernetskii - Nash Dom-Nash Gorod', Ural'skii rabochii, 29 March 1996, p.5, (Electoral advert).

36 Poluchil vlast', peredai dal'she', Ural'skii rabochii, 28 February 1996, p.1. Sverdlovsk Oblast's regional electoral system meant that half of the regional Duma deputies were elected every two years with a four-year mandate.

${ }^{37}$ Rossel' was quick to use his resources against members of local self-government who allied themselves with Chernetskii, for example, Boris Poluiakhtov, the mayor of the city of Kamen'sk-Uralsk (close to Ekaterinburg). On becoming a member of NDNG, Poluiakhtov quickly found himself on the wrong end of regional administrative resources and soon after was defeated in mayoral elections by Viktor Iakimov, the chairman of the Oblast Duma economic and finance policy committee and Rossel' loyalist.
} 
from maintaining its majority in the legislature, although through the pro-Rossel' faction manoeuvred to protect its speaker. Nonetheless, there was little in the party discourse to suggest that the movement was maturing into a regional party with an opportunity to challenge Rossel"s grip on region-wide issues, let alone promote Chernetskii as capable of representing regional interests at the federal level.

The 1998 regional Duma elections were expected to measure Chernetskii's prospects for a gubernatorial challenge in 1999, and NDNG's success encouraged him to compete for the governorship. The limitations of the NDNG movement, and of Chernetskii himself, were highlighted by the ease with which Rossel' was re-elected. According to political analysts at the time, on the basis of clearly being identified as the second most-visible politician in the region, Chernetskii and his electoral team assumed that passage into the second-round was all but a formality and focused the majority of their resources on the expected head-to-head battle with Rossel' in the second round. ${ }^{38}$ His electoral campaign worked towards this aim, but failed to portray Chernetskii as an equal to Rossel' with sufficient potential resources to bring the regional elite to support him. The national political landscape also played a role in this. With the El'tsin regime in steady decline, members of the entire political spectrum of the region were looking for lifeboats ahead of the federal Duma elections. This resulted in members of the political elite seeking to link themselves with Moscow Mayor Iurii Luzhkov's Otechestvo (Fatherland) political party, on the basis that Luzhkov was considered a possibility for the next presidency. ${ }^{39}$ Chernetskii won the regional branch's nomination to become the Sverdlovsk leader of Otechestvo, while Rossel' made no attempts to link himself to the movement, preferring his own. However, the projection of the potential benefits of patronage from Luzhkov offered little additional credibility to Chernetskii's candidacy; the perception of Rossel' as a regional-level actor, who already had the experience and gravitas needed to function at the national level, continued to overpower the attempt to connect Chernetskii with the potential

\footnotetext{
38 Interview with Anatolii Kirillov (Ekaterinburg, March 2011). A good barometer of Chernetskii's position in the political hierarchy are the regular surveys conducted in 1994-95 by the regional press of political analysts and public figures to rate the position of local political actors, in what they called the Politicheskii olimp' (Political Olympus). Although these surveys should be viewed with caution due to their subjective nature and the 'analysts' questioned, it is worth noting that even during the period where Strakhov was governor, Chernetskii was consistently ranked second most-important political figure in the region, above the governor, until shortly before the 1995 gubernatorial elections. Rossel' was consistently ranked first. After Strakhov's defeat and retreat from the Sverdlovsk political scene, there was no-one else able to compete seriously with Rossel' and Chernetskii in this ranking. See for example, 'Politicheskii Olimp ...', Ural'skii rabochii, 11 January 1995, 14 February 1995, 15 March 1995.

39 'God istek, kakoi urok?', Ural'skii rabochii, 15 April 1999, p.2; 'Real'na li silovaia model'?', Ural'skii rabochii, 18 August 1999, p.3.
} 
future leader. The outcome of the first-round of the gubernatorial elections highlighted this mistaken strategy, as Chernetskii failed to reach the run-off election, with Rossel' securing an overwhelming victory in the second-round. ${ }^{40}$

\section{STABILITY OF INTERESTS - THE ROLE OF THE INDUSTRIAL ELITE IN THE BALANCE OF POWER BETWEEN REgIONS AND CitIES}

The protection and incorporation of regional economic interests was critical to Rossel"s political structure, diversifying his networks and incorporating large swathes of the regional population reliant on regional industry for their livelihood. With the breakdown of the Soviet Union's planning, production and distribution system, it quickly became clear to the national economic elite that the state could no longer afford to carry the cost of loss-making sectors that were of much less importance to the new Russian state than they had been to the Soviet Union. ${ }^{41}$ Large industrial enterprises in the region, such as the Uralmash and Khimmash complexes in Ekaterinburg, and Uralvagonzavod and Nizhnii Tagil Metallurgical Plant in Nizhnii Tagil, found themselves seeking an alternative distributor of resources. This gap was filled by Rossel', who sought (financial) resources and distributed them to enterprises in return for them keeping up the social obligations that they had previously been responsible for, and later through the provision of electoral support through influence over employees' voting behaviour.

Rossel"s previous experience as the director of a large enterprise in the region and his vocal support for keeping control of industry within the Urals made him an ideal representative of industrial interests in what was considered to be a highly complex region, politically and economically. The strength of his connection to El'tsin underlined the expectation that he could represent these enterprises nationally, while at the same time finding no contradiction in separating the regional from the local, and working with Chernetskii. ${ }^{42}$ With both the regional and the regional capital executive headed by former industrial managers this elite grouping was confident that they were hedging against any future risk to their interests and conserving their leading influential role in regional politics. As the governor-mayoral conflict developed, particularly in the 1998 regional Duma

\footnotetext{
40 Elena Denezhkina and Adrian Campbell, 'The struggle for power in the Urals', in Cameron Ross and Adrian Campbell (eds.), Federalism and local politics in Russia, (Abingdon: Routledge, 2009), p.211.

${ }^{41}$ Iakov M. Urinson, 'Dostizheniia i oshibki reformatorov', in P.S. Filippov (ed.), Istoriia novoi Rossii: Ocherki, interv'iu v 3 t., Vol. 1, (Saint Petersburg: Norma, 2011), p.92.

42 Interview with Anatolii Kirillov (Ekaterinburg, March 2011).
} 
elections, and 1999 Gubernatorial and Ekaterinburg Mayoral elections, Rossel' realised the necessity of protecting this position as the regional-national representative of industrial affairs. The industrial and economic elite of both city and region acted as a regulating force on the lengths to which competition between the two could escalate. In maintaining the leading role of industry in the region, Rossel' deflected the challenge from rivals by positioning himself as the protector of industry. Following the strong showing of Chernetskii's NDNG party in the 1998 regional Duma elections, Rossel"s strategy in the 1999 gubernatorial elections focused on underscoring the fact that Chernetskii was only relevant in Ekaterinburg. ${ }^{43}$ One of the lines used to discredit the Ekaterinburg mayor was that he represented new merchants rather than the historical traditions of industrial production that the Urals are known for. ${ }^{44}$ By so starkly stating the different arenas of both candidates, Rossel' was deploying boundary control methods to signal to the industrial elite that a vote for Chernetskii risked the region losing its industrial identity and moving towards an unknown post-industrial future (specifically, the replacement of industry with services). While trade was now an important facet of Ekaterinburg's economic structure, industry provided Oblast-wide employment, supported small businesses and dominated entire districts of the city.

The question then arises as to why the Ekaterinburg industrial elites maintained support for Chernetskii as Mayor, and did not seek to consolidate their interests in regional power by working under a unified group. By risking becoming a client of a single patron, who controlled all resources, the city elites maintained competition that forced both patrons to act according to their interests. The different levels of financial and administrative support on offer from the regional and local administration (particularly in the form of tax subsidies and relief) meant that industry benefited from access to two sources of resource distribution. Equally, Rossel' was aware that using more forcible methods to attack Chernetskii, such as through seeking to control and utilise the judiciary, rather than beating him at the polls, would have been seen by this branch of the elite as an attack against the director corps, and would have significantly lowered the opportunity cost to the elite of deserting Rossel'. The results of gubernatorial and mayoral elections in 1999 left everything

\footnotetext{
43 The use of 'political technologies' and 'dirty' PR have been found to have dominated the 1999 gubernatorial elections and the later, post-El'tsin round of competitive Ekaterinburg mayoral elections in 2003. Denezhkina and Campbell (2009), pp.211-213.

${ }^{44}$ Interview with Konstantin Kiselev, (Ekaterinburg, September 2011).
} 
in place as it had been previously; Chernetskii was entrenched as Mayor and Rossel' successfully able to protect his power from an internal threat. ${ }^{45}$

\section{ConClusions}

This article has attempted to discuss two aspects of 1990s Russia. It has presented the boundary control theory as a useful tool for interpreting the preservation of regional power in the uncertain times of the El'tsin decade, contributing to a re-assessment of this period through a mixed approach of formal and informal aspects of power. This permits a focus on individuals and the motivations for their actions rather than solely relying on the development of institutions. Through focusing on the relationships that developed between different branches and levels of power, boundary control provides a framework that can allow for the study of network relationships in Russia with adequate consideration for the context of the times. The use of networks, that either already existed or were constructed by the Sverdlovsk leader, lay at the heart of a system of power, which emphasised Rossel' as a representative of Oblast interests. The value of loyalty of interest groups participating in the regional political system is shown to have been of marked importance in the governor-mayor conflict in Sverdlovsk Oblast. The ability to attract and distribute resources, at both the levels of the Oblast and the regional capital city, became decisive factors in the struggle between Rossel' and Chernetskii, and the three elements of boundary control are shown to have allowed Rossel' to demonstrate that the opportunity costs to the elite of changing patrons were exceedingly high and overly risky. By presenting the conditions of regional power in such a way, there was no requirement for Rossel' to prevent competition to his leadership outright, and he was able to manage the threat posed to him by promoting the personal aspects of his leadership.

As a result, the conflict became essentially stagnant, with both sides remaining in their respective positions. The nature of his ties to El'tsin, and the apparent inability of rivals to establish similar connections, presented Rossel' to the regional elite (and the public)

\footnotetext{
${ }^{45}$ In the 1999 gubernatorial elections Chernetskii won in the city centre Lenin District of Ekaterinburg, but failed to win in the two large industrial districts of the city, Chkalovskii District (Khimmash) and Zheleznodorozhnyi District (Uralmash). Rossel', on the other hand, took all of the larger towns and cities in the oblast surrounding Ekaterinburg, such as Nizhnii Tagil, Kamensk Ural'sk, Pervoural'sk, and Asbest, among others. The second-placed candidate in the first-round of the elections, Alexander Burkov, did not place higher than third in any Ekaterinburg district. See 'Bez vtorogo tura ne oboitis'?', Ural'skii rabochii, 31 August 1999, p.1, and 'Chernetskii: my ne uchli, chto vybory - eto shou', Ural'skii rabochii, 1 September 1999, p.1.
} 
as maintaining Sverdlovsk Oblast's status as one of Russia's key regions, and with an ability to pursue policies at the centre to benefit the local population. Furthermore, Rossel"s control over the regional legislative branch through his Preobrashenie Urala movement required Chernetskii to prise open these boundaries in order to attract elite support away from the regional leader, and so proved impossible to the challenger. The result was that by the end of the El'tsin decade, Rossel' found himself in a position of regional domination, although hegemony was prevented through the checks and balances that the industrial elite provided through its preference for Chernetskii's leadership of the regional capital. The differences between Rossel' and Chernetskii continued well into the next decade, although Chernetskii opted against challenging for the governorship a second time. By the mid2000s, Putin's re-centralization project had threatened the boundaries of Rossel"s domination through its own co-option of the regional elite, forcing Rossel' into adopting a new strategy for power preservation, that of entering into the vertical system of power within the ruling party, Edinaia Rossiia, in order to remain as governor until his retirement in 2009 .

This work is licensed under the Creative Commons Attribution-NonCommercial-ShareAlike 4.0 International License. This license lets others remix, tweak, and build upon the author's work noncommercially, as long as they credit the author and license their new creations under the identical terms. To view a copy of this license, visit bttp:/ / creativecommons.org/licenses/by-nc-sa/4.0/. 